\title{
Global Emotional Intelligence and Six Dimensions of Emotional Intelligence in Indian and Foreign Students with respect to DemographicVariables - (A Comparative Study)
}

\author{
${ }^{1}$ Rahel Tajeddini, ${ }^{2}$ Uma Rangan, ${ }^{3}$ Mohammad Malekzadeh, ${ }^{4}$ Cynthia \\ Lallianzuali \\ I, ( Ph.D In Psychology ) Department Of Psychology University College Of Arts And Social Science Osmania \\ University Hyderabad - 500007Andhra Pradesh - India \\ 2. (Professor In Psychology ) Department Of Psychology University College Of Arts And Social Science \\ Osmania University Hyderabad - 500007Andhra Pradesh - India \\ 3, ( Ph.D In Psychology) Department Of Psychology University College Of Arts And Social Science Osmania \\ University Hyderabad - 500007Andhra Pradesh - India \\ ${ }^{4,}$ M.Phil Rehabilitation Psychology,Department of Rehabilitation Psychology NIMH Secunderabad, Andhra \\ Pradesh - India
}

\begin{abstract}
The concept of Emotional Intelligence has become a very interesting topic of psychological research in recent years. Emotional intelligence is still not completely understood, but the important thing is that Emotions play a very critical role in the overall quality of personal and professional lives.

The purpose of the present research was to study Emotional Intelligence among Indian and Foreign Students with respect to demographic variables ( Gender, age, Educational Qualification, Marital Status, Level of Sociability, Birth Order, Socioeconomic Status and Religion ) - A comparative study. Sample consisted of 400 students . 200 Men and 200 Women.The age range of 20 to 35 years from different Ph.D, M.Phil and MA courses. The sample was drawn from education institutes such as Osmania University ( $O U$ ), English and Foreign Language University (EF L U), Hyderabad Central University (HCU) and Jawaharlal Nehru Technological University ( JNTU ) - India. The number of 32 foreign countries studied and compared with Indian students in this research. Tools used in the present study to collect data was Emotional Intelligence Inventory - $N$ Shutte (1998). Later the data was analyzed by using ANOVA, Independent $t$, Mean Score, Standard Deviation and Pearson Correlation. Results presented that there was no significant differences between Indian and Foreign students with respect to total score of Emotional Intelligence but it was found that Foreign students showed higher Emotional Intelligence as compared to Indian students in two Dimensions of Emotional Intelligence 1- Other's Emotion (Understanding and recognizing other people's emotion) and 2Optimism (A mental attitude or world view that interprets situations and events as being best ). It was concluded from this study that there was no differences between Girls and Boys with respect to Emotional Intelligence .

It was also found that Foreign students showed higher emotional intelligence as compared to Indian students as regards to age group between 25-30. Results also indicated that there was no statistically significant differences between Indian and Foreign students in Emotional Intelligence with respect to the other Demographic variables included to : ( Gender, Educational Qualification, Marital Status, Level of Sociability, Birth Order, Socioeconomic Status and Religion ) in this study.
\end{abstract}

\section{Introduction}

Cultural and political interest in people's Emotional well-being encourages the idea that education should play a prominent role in fostering students' Emotional Intelligence, Self Esteem and self-awareness. This resonates increasingly with a broader therapeutic ethos that supporters claim promotes better personal relationships and democratic processes.

Emotional Intelligence (EI) refers to the ability to perceive, control and evaluate emotions. Some researchers suggest that Emotional Intelligence can be learned and strengthened, while others claim it is an inborn characteristic.

There are many possible definitions of Emotional Intelligence, and many definitions can be found on the Internet. Many of these definitions stem from the popularizations of Emotional Intelligence found in the popular press and in popular books. A clear and scientifically useful definition of Emotional Intelligence, however, is recognizable because it takes the terms emotion and intelligence seriously. 
That is, the meaning of Emotional Intelligence has something specific to do with the intelligent intersection of the emotions and thoughts. Emotional Intelligence represents an ability to validly reason with emotions and to use emotions to enhance thought. Emotional Intelligence is what more than $90 \%$ of the world population are lacking. The label "Emotional Intelligence" is a misnomer, and emotion itself is a grossly misunderstood concept.

[1] have been the leading researchers on Emotional Intelligence. In their influential article "Emotional Intelligence," they defined Emotional Intelligence as, "the subset of social intelligence that involves the ability to monitor one's own and others' feelings and emotions, to discriminate among them and to use this information to guide one's thinking and actions [1].

Emotional Intelligence is the capacity to reason about emotions, and of emotions to enhance thinking. It includes the abilities to accurately perceive emotions, to access and generate emotions so as to assist thought, to understand emotions and emotional knowledge, and to reflectively regulate emotions so as to promote emotional and intellectual growth .

Emotional Intelligence focuses on a number of "inner-side" personal characteristics including understanding, motivation, goal setting ability, confidence, innovation, flexibility and achievement drive. These qualities are vital to individual self development according to [2] Emotional Intelligence also emphasizes on a number of "outer-side" personal characteristics including energizing others, effective leadership, building partnerships, networking, cooperation, wielding influence and developing others. These qualities are critical to individuals to becoming competent in social interaction [2].

\section{Methodology}

The Investigator carried out the enquiry on "Emotional Intelligence \& Self Esteem among Indian and Foreign Students - A Comparative Study. "A part from the Nationality and Gender variables". The other variables that were included in the present study are : Age, Educational Qualification, Marital Status, Level of Sociability, Birth Order, Religion and Socioeconomic Status. The present chapter covers a detailed explanation of the methodology used in this research work .

Various assets like research design, objectives, hypotheses, sample selection, research tools and an account of quantitative and qualitative techniques used for analyzing the data have been elaborated. Data were collected from Osmania University ( OU ) , English and Foreign Language University ( E F L U ) , Hyderabad Central University ( HCU ) and Jawaharlal Nehru Technological University ( JNTU ) keeping in mind the inclusion criteria .

The students were selected based on Gender, Educational Qualification and their Age range ( 20-35 ) After getting consent from the participants, explain about the study the assessment questionnaires of Emotional Intelligence and Demographic variables were given to them. They were instructed to respond all the questionnaires. Sampled data analyzed by :t-test .Measures of central tendency ( mean differences .Measures of variability ( SD ) .ANOVA .TUKEY HSD (Multiple Comparisons). Descriptive statistic analyses and correlation used to interpret the data .

\section{Results}

Hypothesis 1.1.3 There is no difference between Indian and Foreign Students in Emotional Intelligence : is rejected .

Table 1.13 Independent $t$ test for Emotional Intelligence of Indian and Foreign students

\begin{tabular}{|c|c|c|c|c|c|c|c|c|}
\hline & Nationality & $\mathrm{N}$ & Mean & $\mathrm{Sd}$ & $\begin{array}{c}\text { Mean } \\
\text { Difference }\end{array}$ & $\mathrm{t}$ & $\overline{d f}$ & $\begin{array}{l}\text { Sig. (2- } \\
\text { tailed) }\end{array}$ \\
\hline $\begin{array}{c}\text { Emotional } \\
\text { Intelligence }\end{array}$ & $\begin{array}{l}\text { Indian } \\
\text { Foreign }\end{array}$ & $\begin{array}{l}200 \\
200\end{array}$ & $\begin{array}{l}125.72 \\
126.86\end{array}$ & $\begin{array}{l}14.49 \\
12.93\end{array}$ & 1.14 & 0.83 & 397 & 0.43 \\
\hline
\end{tabular}

Findings:

Hence Foreign students showed higher Emotional Intelligence in two dimensions of Emotional Intelligence 1- Other's Emotion ( dimension Understanding and Recognizing Other People s Emotion and 2- ( Optimism ) A mental attitude or world view that interprets situations and events as being best ) as compared to Indian students. But there were no observed significant differences in total score of Emotional Intelligence between Indian and Foreign students. 
Hypothesis 1.2.3 Girls will have a higher Emotional Intelligence than Boys : is rejected .

Table 1.2.3 Independent $t$ test between Boys and Girls with respect to Emotional Intelligence

\begin{tabular}{|c|c|c|c|c|c|c|c|c|}
\hline & Gender & $\mathrm{N}$ & $\mathrm{Mean}$ & $\mathrm{Sd}$ & Mean Difference & & $\mathrm{d}$ & $\begin{array}{c}\text { Sig. (2- } \\
\text { tailed) }\end{array}$ \\
\hline Emotional & Male & 200 & 125.04 & 14.25 & & & & \\
Intelligence & Female & 200 & 127.51 & 13.08 & 2.47 & 1.80 & 398 & .072 \\
& & & & & & & & \\
\hline
\end{tabular}

Findings :

The study didn't show any significant differences between girls and boys with respect to Emotional Intelligence .

Hypothesis 1.3.3 There will be a difference in Emotional Intelligence between Indian and Foreign Students with respect to Demographic Variables : is accepted .

Findings :

- Age

Table 1.3.3

Independent $\mathbf{t}$ test between Indian and Foreign students with respect to age and Emotional Intelligence

\begin{tabular}{|c|c|c|c|c|c|c|c|c|}
\hline $\begin{array}{c}\text { Emotional } \\
\text { Intelligence }\end{array}$ & country & $\mathrm{N}$ & Mean & Std & $\begin{array}{c}\text { Mean } \\
\text { Difference }\end{array}$ & $\mathrm{t}$ & $\overline{d f}$ & Sig. (2-tailed) \\
\hline \multirow[t]{2}{*}{$\operatorname{Age1}(20-25)$} & Indian & $\overline{143}$ & 126.27 & 13.651 & \multirow[t]{2}{*}{0.77} & \multirow[t]{2}{*}{.438} & \multirow[t]{2}{*}{234} & \multirow[t]{2}{*}{.662} \\
\hline & Foreign & 93 & 125.50 & 12.64 & & & & \\
\hline \multirow[t]{2}{*}{ Age2(25-30) } & Indian & 39 & 122.10 & 17.38 & \multirow[t]{2}{*}{2.376} & \multirow[t]{2}{*}{105} & \multirow[t]{2}{*}{.019} & \multirow[t]{2}{*}{2.376} \\
\hline & Foreign & 68 & 128.95 & 12.32 & & & & \\
\hline \multirow[t]{2}{*}{ Age3(30-35) } & Indian & 18 & 129.11 & 13.51 & \multirow[t]{2}{*}{2.82906} & \multirow[t]{2}{*}{.705} & \multirow[t]{2}{*}{55} & \multirow[t]{2}{*}{.484} \\
\hline & Foreign & 39 & 126.28 & 14.33 & & & & \\
\hline
\end{tabular}

Graph 1.1.3

The mean and standard deviation between Indian and Foreign students with respect to Age and Emotional Intelligence (age 25-30)

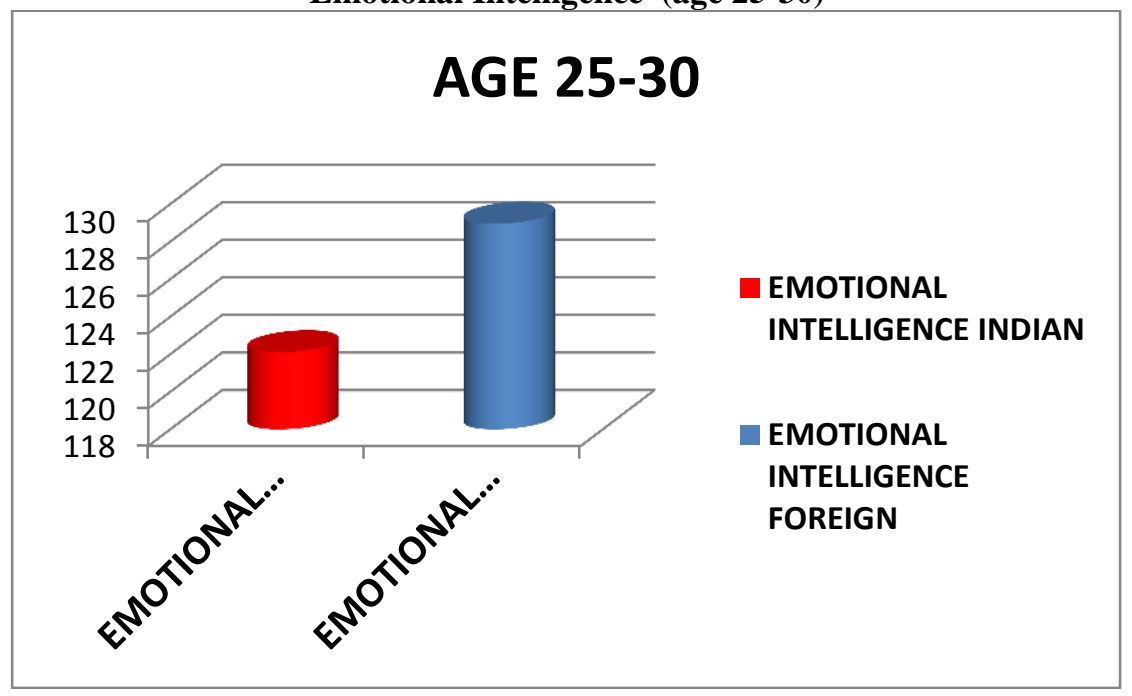

Forasmuch as Table and Graph, it was observed that there was statistically significant differences between Foreign and Indian students in 25 to 30 age range with respect to Emotional Intelligence. By considering the obtained value of sig ( 2-tailed - 0.19) and as for analysis of t-test performed on scores of Age group ( 25-30) and citing the mean scores differences between Indian and Foreign students in this property ( Foreign : 128.9559 and Indian : 122.1026) indicated that Foreign students have higher Emotional Intelligence as compared to Indian students in this study . 
- Educational Qualification

Table 1.4.3

Independent $\mathbf{t}$ test between Indian and Foreign students with respect to Emotional Intelligence and Educational Qualification

\begin{tabular}{|c|c|c|c|c|c|c|c|c|}
\hline $\begin{array}{c}\text { Emotional } \\
\text { Intelligence }\end{array}$ & $\overline{\text { country }}$ & $\mathrm{N}$ & Mean & Std & $\begin{array}{c}\text { Mean } \\
\text { Difference }\end{array}$ & $\mathrm{t}$ & $\mathrm{df}$ & $\begin{array}{l}\text { Sig. (2- } \\
\text { tailed) }\end{array}$ \\
\hline \multirow[t]{2}{*}{ Ph.D } & Indian & 24 & 121.87 & 19.06 & \multirow[t]{2}{*}{1.63929} & \multirow[t]{2}{*}{.371} & \multirow[t]{2}{*}{57} & \multirow[t]{2}{*}{.712} \\
\hline & Foreign & 35 & 123.51 & 14.80 & & & & \\
\hline \multirow[t]{2}{*}{ M.Phil } & Indian & 10 & 133.70 & 15.79 & \multirow[t]{2}{*}{12.86} & \multirow[t]{2}{*}{1.821} & \multirow[t]{2}{*}{14} & \multirow[t]{2}{*}{.090} \\
\hline & Foreign & 6 & 120.83 & 8.65 & & & & \\
\hline \multirow[t]{2}{*}{ МА } & Indian & 166 & 125.79 & 13.53 & \multirow[t]{2}{*}{1.99} & \multirow[t]{2}{*}{1.377} & \multirow[t]{2}{*}{323} & \multirow[t]{2}{*}{.170} \\
\hline & Foreign & 159 & 127.78 & 12.48 & & & & \\
\hline
\end{tabular}

In this particular Table the results of the hypothesis (There will be a difference in Emotional Intelligence between Indian and Foreign students with respect to Educational Qualification have been divided respectively to 3 section. 1- The students who were doing Ph.D. 2- The students who were doing M.phil and 3- The students who were doing Master. The above table shows the obtained value of sig ( 2-tailed - 07120) and by the analysis of t-test, it is illustrated that there were no statistically significant differences between Indian and Foreign students in Emotional Intelligence with respect to Educational Qualification in this study .

- Marital Status

Table 1.5.3

Independent $t$ test in Indian and Foreign students with respect to Marital Status and Emotional Intelligence

\begin{tabular}{|c|c|c|c|c|c|c|c|c|}
\hline $\begin{array}{l}\text { Emotion } \\
\text { al Intelligence }\end{array}$ & country & $\mathrm{N}$ & Mean & Std & $\begin{array}{c}\text { Mean } \\
\text { Difference }\end{array}$ & $\mathrm{t}$ & $\mathrm{df}$ & $\begin{array}{l}\text { Sig. (2- } \\
\text { tailed) }\end{array}$ \\
\hline \multirow[t]{2}{*}{ Married } & Indian & 28 & 126.35 & 16.03 & \multirow[t]{2}{*}{.92} & \multirow[t]{2}{*}{.274} & \multirow[t]{2}{*}{75} & \multirow[t]{2}{*}{.785} \\
\hline & Foreign & 35 & 49 & 127.28 & & & & \\
\hline \multirow[t]{2}{*}{ Single } & Indian & 171 & 125.70 & 14.27 & \multirow[t]{2}{*}{.97} & \multirow[t]{2}{*}{.641} & \multirow[t]{2}{*}{320} & \multirow[t]{2}{*}{.522} \\
\hline & Foreign & 151 & 126.68 & 12.84 & & & & \\
\hline
\end{tabular}

Table 1.5.3 shows the results of this hypothesis (There will be a difference in Emotional Intelligence between Indian and Foreign students with respect to Marital Status ) have been considered respectively as two gropus . 1 - The participants who got married and 2- The participants who were single . By considering the above results and the obtained value of sig ( 2 -tailed- 0.785 for single students and the value of sig 2 -tailed0.522 for married students ) and citing the analysis of t-test inferred that there were no statistically significant differences between Married and Single Indian students and Married and Single Foreign students with respect to Emotional Intelligence. It was indicated that Marital Status were not be a relevant property in association with Emotional Intelligence in this study .

\section{- Level of Sociability}

Table 1.6.3

Independent $t$ test in Indian and Foreign students with respect to Level of Sociability and Emotional Intelligence

\begin{tabular}{|c|c|c|c|c|c|c|c|c|}
\hline $\begin{array}{c}\text { Emotional } \\
\text { Intelligence }\end{array}$ & country & & & & $\begin{array}{c}\text { Mean } \\
\text { Difference }\end{array}$ & $\mathrm{t}$ & $\begin{array}{c}\text { df } \\
\text { Sig. (2- } \\
\text { tailed) }\end{array}$ \\
\hline $\begin{array}{c}\text { Level of } \\
\text { Sociability } \\
\text { never }\end{array}$ & Indian & 14 & 117.35 & 16.79 & 5.14 & 1.071 & 34 & .292 \\
\cline { 2 - 10 } & Foreign & 22 & 122.50 & 12.02 & & & & \\
\hline $\begin{array}{c}\text { Level of } \\
\text { Sociability } \\
\text { Some Times }\end{array}$ & Indian & 150 & 126.72 & 13.00 & 62194 & .419 & 303 & .676 \\
\hline $\begin{array}{c}\text { Level of } \\
\text { Sociability } \\
\text { Frequently }\end{array}$ & Indian & 36 & 124.80 & 18.36 & 1.99 & .613 & 57 & .542 \\
\cline { 2 - 10 }
\end{tabular}


In according to Table 1.6.3 the results of this hypothesis (There will be a difference in Emotional Intelligence with respect to Level of Sociability have been divided to 3 sections between Indian and Foreign students in different countries 1- The students who Never go to any parties 2- The students who Some times go to any parties and 3- The students who Frequently go to any parties. In above table the analysis on data shows that the obtained value of t-test and sig ( 2 -tailed ) for these three groups respectively ( Never : 0.292 , Some times :0.676 and Frequently: 0.542 ) Hence by considering the obtained results the differences between mean scores were not be statistically significant in these three groups of participants..The analysis of independent sample test revealed that there were no meaningful differences between Emotional Intelligence and Social Functions among Indian and Foreign students. It noticed that there were no relevant between Emotional Intelligence among Indian and Foreign students with respect to level of sociability in this research.

\section{- Birth Order}

Table 1.7.3

Independent $\mathbf{t}$ test in Indian and Foreign students with respect to Birth Order and Emotional Intelligence

\begin{tabular}{|c|c|c|c|c|c|c|c|c|}
\hline Emotional Intelligence & country & $\mathrm{N}$ & Mean & Std. & $\begin{array}{c}\text { Mean } \\
\text { Difference }\end{array}$ & $\mathrm{t}$ & df & $\begin{array}{l}\text { Sig. }(2- \\
\text { tailed) }\end{array}$ \\
\hline $\begin{array}{c}\text { Birth Order. First } \\
\text { child }\end{array}$ & $\begin{array}{c}\text { Indian } \\
\text { Foreign }\end{array}$ & $\begin{array}{l}94 \\
73\end{array}$ & $\begin{array}{l}126.37 \\
123.35\end{array}$ & $\begin{array}{l}13.99 \\
13.14\end{array}$ & 3.01 & 1.418 & 165 & .158 \\
\hline $\begin{array}{c}\text { Birth Order .Second } \\
\text { child }\end{array}$ & $\begin{array}{c}\text { Indian } \\
\text { Foreign }\end{array}$ & $\begin{array}{l}57 \\
48\end{array}$ & $\begin{array}{l}124.36 \\
125.60\end{array}$ & $\begin{array}{l}14.13 \\
13.99\end{array}$ & 1.23 & .448 & 103 & .655 \\
\hline $\begin{array}{c}\text { Birth Order .Third } \\
\text { child }\end{array}$ & $\begin{array}{c}\text { Indian } \\
\text { Foreign }\end{array}$ & $\begin{array}{l}27 \\
35\end{array}$ & $\begin{array}{l}126.22 \\
130.17\end{array}$ & $\begin{array}{l}15.53 \\
11.43\end{array}$ & 3.949 & 1.153 & 60 & .253 \\
\hline $\begin{array}{l}\text { Birth Order More } \\
\text { than Three }\end{array}$ & $\begin{array}{c}\text { Indian } \\
\text { Foreign }\end{array}$ & $\begin{array}{l}22 \\
44\end{array}$ & $\begin{array}{l}125.81 \\
131.27\end{array}$ & $\begin{array}{l}16.90 \\
10.64\end{array}$ & 5.45455 & 1.602 & 64 & .114 \\
\hline
\end{tabular}

Citing the Table 1.7.3 the results of this hypothesis (There will be a difference in Emotional Intelligence with respect to Birth Order have been cleaved to 4 sections respectively among Indian and Foreign participants. 1- The students who were born as first child 2- The students who were born as second child 3- The students who were born as third child and 4- The students who were born as more than three in this study). The above table illustrates the analysis of independent sample test and the obtained value of sig ( 2-tailed for all four groups of participants respectively) . sig -2tailed for first child : 0.158 . sig 2-tailed for second child : 0.655 . sig - 2-tailed for Third child :0.253 and finally sig - 2-tailed for More ths three child were $: 0.114$. Citing the obtained results indicate that there were no statistically significant differences related to Emotional Intelligence and Birth Order.

\section{- Religion}

Table 1.8.3

Independent $\mathbf{t}$ test in Indian and Foreign students with respect to Religion and Emotional Intelligence

\begin{tabular}{|c|c|c|c|c|c|c|c|c|}
\hline Emotional Intelligence & country & $\mathrm{N}$ & Mean & Std. & $\begin{array}{c}\text { Mean } \\
\text { Difference }\end{array}$ & $\mathrm{t}$ & df & $\begin{array}{l}\text { Sig. (2- } \\
\text { tailed) }\end{array}$ \\
\hline Religion Agnostic & $\begin{array}{c}\text { Indian } \\
\text { Foreign }\end{array}$ & $\begin{array}{l}26 \\
29\end{array}$ & $\begin{array}{l}120.53 \\
118.96\end{array}$ & $\begin{array}{l}14.62 \\
11.59\end{array}$ & 1.57294 & .444 & 53 & .659 \\
\hline Religion Hindu & $\begin{array}{c}\text { Indian } \\
\text { Foreign }\end{array}$ & $\begin{array}{c}131 \\
14\end{array}$ & $\begin{array}{l}126.62 \\
127.57\end{array}$ & $\begin{array}{l}13.73 \\
11.80\end{array}$ & .945 & .248 & 143 & .805 \\
\hline Religion Christian & $\begin{array}{c}\text { Indian } \\
\text { Foreign }\end{array}$ & $\begin{array}{l}19 \\
21\end{array}$ & $\begin{array}{l}128.36 \\
129.04\end{array}$ & $\begin{array}{c}13.12 \\
13.672\end{array}$ & 67920 & .160 & 38 & .874 \\
\hline Religion Muslim & $\begin{array}{c}\text { Indian } \\
\text { Foreign }\end{array}$ & $\begin{array}{c}24 \\
128\end{array}$ & $\begin{array}{l}124.29 \\
127.79\end{array}$ & $\begin{array}{l}18.52 \\
12.64\end{array}$ & 3.50521 & 1.149 & 150 & .252 \\
\hline
\end{tabular}

As for Table 1.8.3 the results of this hypothesis (There will be a difference in Emotional Intelligence with respect to Religion have been disparted to 4 sections among Indian and other countries respectively. 1The participants who conformance Agnostic ( The people who don't believe the God ) 2- The participants who following Hind 3- The participants who believe Christianity and 4- The students who adherence Islam . The above tables represent that there were no statistically significant differences between Foreign and Indian students with respect to Religion and Emotional Intelligence . The analysis of t-test performed on scores of these groups and citing the obtained value of sig ( 2-tailed ) between Indian and Foreign students with respect to Religion and Emotional Intelligence. Hence there were no statistically differences in this hypothesis. 


\section{- Socioeconomic Status}

Table 1.9.3

Independent $\mathbf{t}$ test in Indian and Foreign students with respect to Socioeconomic Status and Emotional Intelligence

\begin{tabular}{|c|c|c|c|c|c|c|c|}
\hline Emotional Intelligence & country & $\mathrm{N}$ & Mean & Std. & $\begin{array}{c}\text { Mean } \\
\text { Difference }\end{array}$ & $\begin{array}{c}\text { Sig. (2- } \\
\text { tailed) }\end{array}$ \\
\hline $\begin{array}{c}\text { Low Socioeconomic } \\
\text { Status }\end{array}$ & Indian & 22 & 124.68 & 13.12 & & \\
Foreign & 7 & 123.57 & 6.18 & 1.11 & .214 \\
\hline $\begin{array}{c}\text { Middle Socioeconomic } \\
\text { Status }\end{array}$ & Indian & 167 & 126.15 & 14.14 & & \\
& Foreign & 170 & 127.42 & 12.97 & 1.27 & .862 \\
\hline High Socioeconomic & Indian & 11 & 121.18 & 21.77 & & 335 \\
Status & Foreign & 23 & 123.39 & 13.68 & 2.20 & .369 \\
\hline
\end{tabular}

Based on Table 1.9.3 the results of this hypothesis (There will be a difference in Emotional Intelligence with respect to Socioeconomic Status ) have been cleaved to 3 sections 1- The participants who have Low Socioeconomic Status , 2- The students who have Middle Socioeconomic Status and 3- The students who have High Socioeconomic Status. The above tables shows that the analysis of t-test and The obtained value of sig 2-tailed for these three groups respectively ), Low Economic Status : 0.832 . Middle Economic Status : 0.389 and High Economic Status : 0.720 .Hence citing the observed results there were no statistically significant differences between Emotional Intelligence and Socioeconomic Status in this research.

Hence the Foreign students showed a higher Emotional Intelligence as compared to Indian students as regards to age group between 25-30. There were no observed any statistically differences between Indian and Foreign students with respect to the other demographic variables (educational qualification, marital status, level of sociability ,birth order, socioeconomic status and religion ) in this study .

\section{Discussion}

1) The first hypothesis that there is no difference between Indian and Foreign Students in Emotional Intelligence was analyzed. The results clearly indicates that there is no statistically significant differences between Indian and Foreign students in total score of Emotional Intelligence but there is significantly differences between Indian and Foreign students in two dimensions of Emotional Intelligence that included to : 1- Other's Emotion and 2- ( Optimism ). Not exist any research on particular part on Emotional Intelligence among Indian and Foreign students but [3] examined the relationship among dimensions of Emotional Intelligence as predictor variables of organizational citizenship behaviour among Indian .

finding of the present study and that of the earlier research confirm that Indian students showed low Emotional Intelligence in those dimension of Emotional Intelligence that was expressed ( other's emotion . own emotion and social skills ).

2) The second objective in this study was assigned to identify Gender difference with respect to Emotional Intelligence. The results clearly showed that there is no statistically significant between Boys and Girls in Emotional Intelligence.

Not exist any research on particular part on Indian and Foreign students in Emotional Intelligence [4] indicated the study on Emotional Intelligence among male and female. The research sample was comprised of one hundred and sixty subjects who were categorized in two groups.. They were eighty males and eighty females from the students of Islamic azad university in karaj , Iran . Gender difference on Emotional Quotient Inventory reveals that there is no differences between Males and Females .

Finding of the present study and that of the earlier research confirm that there is no differences between boys and girls with respect to Emotional Intelligence. But [5] presented the antithetical findings with respect to gender and Emotional Intelligence .Researchers conducted a study on Relationship Between Gender and Emotional Intelligence. The results found that girls are higher than boys in Emotional Intelligence, but high Emotional Intelligence in boys is a better predictor for achievement .

More telling is the fact Girls have higher Emotional Intelligence than boys . Citing this finding, [6] studied on 150 students of Xth class from different Government Schools in Chandigarh for assessment of gender differences in Emotional Intelligence. The data was collected through standardized "Emotional Intelligence Test". The findings revealed that majority of boys, girls and the total sample had good followed by low Emotional Intelligence. Girls were found to have higher Emotional Intelligence than that of boys .

The different in results can be attributed to highly competitive nature of the study. And girls might have put more amount of efforts toward developing Emotional Intelligence as compared to boys . Another reason could be the difference is society which sample is collected from that, in present study sample is 
collected from 33 countries who live in Hyderabad - India but in the other research which found opponent result , sample gathered from only Indian adolescence in Chandigarh - India. The other reason might be because of age differences. The age range in present study was 20 to 35 but the age range in opponent research finding was only Adolescence

3) One of the other major objectives in this study was to assess the Emotional Intelligence with respect to Demographic Variables ( age , educational qualification , marital status , level of sociability , birth order , religion, and socioeconomic status ). The results revealed that there is significant differences between Indian and Foreign students in Emotional Intelligence with respect to age ( 25-30) and there was no statistically differences between Emotional Intelligence with respect to the other demographic variables among Indian and Foreign students in this study.

No exist any research on particular part in Indian and Foreign students but [7] conducted a study of 405 American people between 22 and 70 years old which showed that Emotional Intelligence increases slightly with age. The relationship was slight but significant. The results showed that older people are slightly more likely to be higher in Emotional Intelligence. The finding suggests Emotional Intelligence is a developing ability, it is likely that accumulated life experience contribute to Emotional Intelligence .

The findings of the present study and findings of [7] is in consonance which older students showed higher Emotional Intelligence as compared to younger students. Another research findings presented by [8] support the significant differences between Emotional Intelligence and age . [8] presented the study on Influence of Demographic Profiles on Emotional Intelligence: A Study on Polytechnic Lecturers in Malaysia .Demographic profiles such as age, gender, group, occupational grade, working experience in the current job and prior working experience in the industry are selected.

On the other hand the lack of significant differences between Emotional Intelligence and marital status is in conflict with research findings of [9] presented A comparative investigation that is contradicts present finding, in their study some of the personality characteristics, Emotional Intelligence, depression , anxiety ,stress among the single and married students was studied .Sample consisted of 900 single and married students studying in the country (cities of Tehran, Karaj; Levasanat, Shahreray, Kermanshah, Ahvaz, Pakdasht) were selected .

In the present study the sample size was 400 which divided to Indian and Foreign students ,the frequency of married students was 77 with 19.3 percentage and 323 single students with 80.8 percentage hence sample size in present study was less as compared to the opponent finding. On the other hand the present study conducted in India among 32 countries as compared to Indian students while the other research which is in conflict, conducted in Iran among only Iranian students. Hence maybe the structural differences between these two studies in sample and society Resulted in a different outcome.

The finding are further consistent with research conducted by [10] This research studied the Emotional Intelligence levels of university students in the context of demographic variables of students included to ( Religion, Sociability and Socioeconomic status ) For this purpose, a questionnaire was filled in by 200 students studying at five different faculties of Çanakkale Onsekiz Mart University. Age range was 20 to 30 .

The results of the research revealed that there is not any significant difference in the relationship between the faculty of students and their Emotional Intelligence with respect to religion and this findings is in consonance with present study but [33] showed that there is significantly differences between Emotional Intelligence and sociability and socioeconomic status which is in conflict with presnt finding in current research .

\section{Major Findings}

\section{The findings of the study are presented under the following headlines :}

1) results presented that there was no significant differences between Indian and Foreign students with respect to total score of Emotional Intelligence but it was found that Foreign students showed higher Emotional Intelligence as compared to Indian students in two dimensions of Emotional Intelligence in this study, 1Other's Emotion and 2- Optimism .

2) It can be concluded from this study that there was no differences between girls and boys with respect to Emotional Intelligence .

3) It was found that Foreign students showed higher Emotional Intelligence as compared to Indian students as regards to age group between 25-30 .

4) There was no statistically significant differences between Indian and Foreign students in Emotional Intelligence with respect to the other demographic variables included to : ( gender, educational qualification, marital status, level of sociability ,birth order, socioeconomic status and religion ) in this study. 


\section{Conclusion}

Results also indicated that Foreign students showed higher Emotional Intelligence only in two dimensions of Emotional Intelligence 1- Other's Emotion ( Understanding and Recognizing Other People s Emotion ) and 2- Optimism (A mental attitude or world view that interprets situations and events as being best ) as compared to Indian students. The results differences in Emotional Intelligence and Self Esteem between Indian and Foreign students concluded in this study were may be because of several factors outcomes of the life qualitative environment and also cultural differences. And there was no differenced between Indian and Foreign students in total mean score of Emotional Intelligence in this study .

The present study illustrates that there were no differences between girls and boys with respect to Emotional Intelligence .

Further the study noticed that the Foreign students showed higher Emotional Intelligence as compared to Indian students as regards to age group between 25-30 and There were no observed any statistically differences between Indian and Foreign students with respect to the other demographic variables ( gender, educational qualification, marital status, level of sociability, birth order, socioeconomic status and religion ) in this study. The difference in Emotional Intelligence between age groups may be because of encounter with more obstacles and challenges and effort to over come on them in their life. Hence the students who were 25 30 got higher scores in Emotional Intelligence as compared to students with $20-25$ years old .

\section{Implication}

1-There are several implications for the results of this study. Firstly the future researchers can consider this findings for the future studies .

2- The findings of study elucidate that Self Esteem can be influenced by age .

3- The other implication of this study is to help the psychologists for getting a good case history based on the Effective factors on Emotional Intelligence ( age, gender, nationality, educational qualification, marital status , level of sociability ,birth order, socioeconomic status and religion ) as regards to the current research .

4-The finding of the present study also project the need to introduce certain relevant Intervention programs to maintain good Emotional Intelligence and mental health.

\section{Recommendation}

1- Future study should have greater consideration in assessing the social cultural factors influencing Emotional Intelligence .

2- On the basis of the findings measures can be taken to study elderly as regards to Emotional Intelligence.

3-The investigative study focused exclusively on four main universities in Hyderabad ; thus there is a need future study to be directed toward other universities or even industrial companies and Behavioural Sciences organizations. Hence application of this research should take different places. By conducting this research in various locations, more reliable results would be garnered and Indian students across geographic locations would be targeted.

4-Future researches need to ask the question as to whether or not the role of parents, schools, life styles, childhood milestone on Reinforcement and/or debilitation of Emotional Intelligence.

5-Media can be used to develop the necessary of Emotional Intelligence by putting up audio/video training programs on the basic tenets.

6- It would be interesting to make comparative study on Emotional Intelligence between urban and rural students.

7- Needs to ask the role of quality of life on Emotional Intelligence in the future studies .

8- Fields of study such as philosophy, sociology, political science, anthropology, and zoology might have perspectives on Emotional Intelligence that would increase the utility of the construct across fields, and suggest additional approaches to developing.emotional-intelligence.

\section{References}

[1] J D. Mayer ,University of New Hampshire, USA, P Salovey,Yale University, USA (2004 ) Emotional Intelligence and the construction and regulation of feelings.

[2] Goleman, D. (1998). Working with Emotional Intelligence. New York: Bantam.

[3] J.J Maini ( 2007 ) the relationship among dimensions of Emotional Intelligence as predictor variables of organizational citizenship behaviour among Indian .

[4] M,J Samavati ( 2009) the study on Emotional Intelligence among male and female.

[5] F. Naghavi, M. Redzuan (2011) the antithetical findings with respect to gender and Emotional Intelligence .

[6] S. Katyal and E. Awasthi ( 2005 ) studied on 150 students of Xth class from different Government Schools in Chandigarh for assessment of gender differences in Emotional Intelligence.

[7] L. Fariselli. M. Ghini , J. Freedman ( 2006) a study of 405 American people between 22 and 70 years old which showed that Emotional Intelligence increases slightly with age.

[8] J. A. Kumar and B. Muniandy ( 2012 ) Emotional Intelligence and age 
[9] H. Kamarzarrin, M. khaledian, M. Shooshtari, M. A. Tosang ( 2013) A comparative investigation on personality characteristics, Emotional Intelligence, depression , anxiety ,stress among the single and married students was studied .

[10] N. Yelkikalan, G. Hacioglu and A. Kiray University students, Turkey ( 2008) Emotional Intelligence levels of university students in the context of demographic variables of students included to (Religion, Sociability and Socioeconomic status ). 